Revue bibliographique pour le domaine irano-aryen

\title{
Eric Wright, Miles Branum. Eastern Christianity: A Look at Its Tradition and Theology
}

\section{Florence Jullien}

\section{(2) OpenEdition \\ 12 Journals}

\section{Édition électronique}

URL : http://journals.openedition.org/abstractairanica/40905

DOI : 10.4000/abstractairanica.40905

ISSN : 1961-960X

Éditeur :

CNRS (UMR 7528 Mondes iraniens et indiens), Éditions de l'IFRI

\section{Édition imprimée}

Date de publication : 1 décembre 2013

ISSN : 0240-8910

\section{Référence électronique}

Florence Jullien, « Eric Wright, Miles Branum. Eastern Christianity: A Look at Its Tradition and Theology ", Abstracta Iranica [En ligne], Volume 32-33 | 2013, document 354, mis en ligne le 01 juillet 2016, consulté le 03 octobre 2020. URL : http://journals.openedition.org/abstractairanica/40905; DOI : https://doi.org/10.4000/abstractairanica.40905

Ce document a été généré automatiquement le 3 octobre 2020.

Tous droits réservés 


\section{Eric Wright, Miles Branum. Eastern Christianity: A Look at Its Tradition and Theology}

Florence Jullien

\section{RÉFÉRENCE}

Eric Wright, Miles Branum. Eastern Christianity: A Look at Its Tradition and Theology.

Webster's Digital Services, 2010, 162 p.

1 Ces deux ouvrages parus conjointement ne sont pas œuvres de spécialistes mais le fruit d'une synthèse de données encyclopédiques prises sur internet, sans regard critique et sans accès direct aux sources. Cette méthode est celle que proposent les éditeurs de la collection promue par Webster's Digital Services, qui ne prétend à aucun travail de type scientifique mais plutôt compilatoire.

2 [Ce compte rendu concerne également le $n^{\circ}$ 355]

\section{AUTEURS}

FLORENCE JULLIEN

EPHE, Paris 